\title{
Oxidative sulfur cycling in the deep biosphere of the Nankai Trough,
} Japan

\author{
N. Riedinger ${ }^{1 *}$, B. Brunner ${ }^{1}$, M.J. Formolo ${ }^{1}$, E. Solomon², S. Kasten ${ }^{3}$, M. Strasser ${ }^{4}$, and T.G. Ferdelman ${ }^{1}$ \\ ${ }^{1}$ Max Planck Institute for Marine Microbiology, Celsiusstraße 1, 28359 Bremen, Germany \\ ${ }^{2}$ School of Oceanography, University of Washington, Box 355351, Seattle, Washington 98195-5351, USA \\ ${ }^{3}$ Alfred Wegener Institute for Polar and Marine Research, Am Handelshafen 12, 27570 Bremerhaven, Germany \\ ${ }^{4}$ MARUM, Center for Marine Environmental Sciences, University of Bremen, Leobener Straße, 28359 Bremen, Germany
}

\begin{abstract}
The existence of oxidative microbial sulfur cycling in the deep biosphere has been postulated, but it is difficult to identify because isotope effects of reductive sulfur cycling generally overprint those of oxidative sulfur cycling. In the sediments at Integrated Ocean Drilling Program (IODP) Site C0007 (Holes A-C) drilled and sampled during IODP Expedition 316 at the Nankai Trough, Japan, sulfur and oxygen isotope compositions of dissolved and solid-phase sulfur compounds show evidence for a discrete zone of deep oxidative sulfur cycling. The sulfate concentration profile and isotope values show two distinct sulfate reduction regimes: one for downward-diffusing sulfate in the uppermost $36 \mathrm{~m}$ of sediment (unit I), and another zone below $90 \mathrm{~m}$, where sulfate diffuses upward from a deep subsurface fluid. The sulfur and oxygen isotope composition of sulfate and a dramatic change in solid-phase iron geochemistry indicate that oxidative sulfur cycling occurs at depth. The highly dynamic sedimentary and tectonic regime at Nankai Trough has created an environment in the subsurface where geochemical gradients can sustain deep oxidative sulfur cycling over long durations of time.
\end{abstract}

\section{INTRODUCTION}

Oxidative sulfur cycling is a well-known phenomenon at the sea bed (Jørgensen, 1982, 1990). Even in strictly anoxic subseafloor environments, the oxidation of sulfide occurs via nitrate reduction or by simultaneous reduction of metal oxides, e.g., iron (oxyhydr)oxides: $2 \mathrm{FeOOH}+\mathrm{HS}^{-}+5 \mathrm{H}^{+} \leftrightarrow 2 \mathrm{Fe}^{2+}+\mathrm{S}^{0}+4 \mathrm{H}_{2} \mathrm{O}$ (Canfield, 1989; Thamdrup et al., 1993; Jørgensen and Nelson, 2004). The latter process depends on the availability, accessibility, and reactivity of metal oxides (Canfield, 1989). Elemental sulfur $\left(\mathrm{S}^{0}\right)$, produced by the oxidation of sulfide with metal oxides, can be metabolized by sulfur-disproportionating bacteria to produce sulfate and sulfide: $4 \mathrm{~S}^{0}+4 \mathrm{H}_{2} \mathrm{O} \leftrightarrow 3 \mathrm{H}_{2} \mathrm{~S}$ $+\mathrm{SO}_{4}{ }^{2-}+2 \mathrm{H}^{+}$(see Jørgensen and Nelson, 2004, and references therein). Disproportionation of $\mathrm{S}^{0}$ is thermodynamically favorable if sulfide is sequestered into the solid sulfide pool or reoxidized to $S^{0}$. The supply of oxygen and nitrate deeper below the seafloor is limited by microbial consumption at shallow depth; however, metal oxides can also be available at greater depth (e.g., Riedinger et al., 2005). Therefore, oxidation of sulfide to $S^{0}$ and subsequent disproportionation to sulfide and sulfate are processes that could occur at any sediment depth, as long as reactive metal oxides are available and sulfide is efficiently scavenged.

\footnotetext{
*Current address: Department of Earth Sciences, Biogeochemistry, University of California-Riverside, 900 University Avenue, Riverside, California 925210432, USA; E-mail: natascha.riedinger@ucr.edu.
}

Bacterial disproportionation of $\mathrm{S}^{0}$ has been invoked to explain large sulfur isotope offsets $(>49 \%$ ) observed between sulfides and sulfate (Canfield and Thamdrup, 1994; Habicht and Canfield, 2001). It has been presumed that isotope fractionations larger than $49 \%$ may be indicative of disproportionation. However, this view has been challenged by Wortmann et al. (2001), Rudnicki et al. (2001), and theoretical considerations by Brunner and Bernasconi (2005), who suggest that sulfur isotope fractionations up to $70 \%$ may also be directly caused by dissimilatory sulfate reduction. Therefore, from sulfur isotope systematics alone, it may be difficult to evaluate the importance of either process. In the sediment and pore-water profiles, oxidative sulfur cycling may go completely undetected as long as there is an overlap between sulfate reduction and simultaneous disproportionation, mimicking pure sulfate reduction. In a continuous, steady-state sediment system, there is little chance to observe oxidative sulfur cycling within the deep biosphere. Therefore, a system that offers the potential to observe the separation between reductive and oxidative sulfur cycling is needed.

The Nankai Trough is a suitable system to study the oxidative sulfur cycle due to its depositional and tectonic features. Subduction of the Philippine Sea plate below southwest Japan results in frontal accretion, uplift, and internal deformation of the trench wedge and underlying Shikoku Basin sediments (Underwood et al., 2003; Strasser et al., 2009). This setting is characterized by a complex lithostratigraphy and depositional history, with varying sedi- mentation rates, sediment composition, organic matter content, and availability of reactive iron minerals, all of which dramatically affect the oxidative capacity and permeability of sediments. Thrust faults and interbedded gravels and sands deposited in the axial trench and uplifted in the frontal prism accommodate lateral fluid flow that transports oxygen, nitrate, and sulfate into the subseafloor. The content of degradable organic matter and reactive metal oxides can change within narrow zones. The Nankai accretionary wedge thus directly juxtaposes various redox environments and their corresponding geochemical gradients and serves to spatially separate the oxidative sulfur cycle from reductive sulfur cycling.

Here, we present results of iron and sulfur geochemistry of sediments from the frontal thrust system at the Nankai Trough (Hole C0007A-C), off Japan, collected during the Integrated Ocean Drilling Program (IODP) 316 Expedition. We determined the sulfur isotope composition of elemental sulfur $\left(\mathrm{S}^{0}\right)$, acid volatile sulfur (AVS), chromium reducible sulfur (CRS), and the sulfur and oxygen isotope composition of pore-water sulfate (for methods, see the GSA Data Repository ${ }^{1}$ ). These data identify the presence of a dominant oxidative sulfur cycle in a zone between sediment layers where active sulfate reduction occurs.

\section{SEDIMENTARY SETTING}

Drilling and coring at Hole C0007A-C (see the Data Repository) recovered sediment from two major lithologic units (Figs. 1 and 2; Kinoshita et al., 2009; Screaton et al., 2009): Unit I (trench to slope transition) is characterized by a fining-upward succession of hemipelagic silty clay with interbedded thin sand beds and volcanic ash layers. Deposition of this unit occurred on the lowermost slope of the prism above the trench floor by hemipelagic settling, turbidite deposition, and possibly subsequent soft-sediment slumping on an oversteepened slope. Unit II is an accreted trench-wedge facies

${ }^{1}$ GSA Data Repository item 2010236, detailed description of sample handling and analytical methods, is available online at www.geosociety.org/pubs/ ft2010.htm, or on request from editing@geosociety .org or Documents Secretary, GSA, P.O. Box 9140, Boulder, CO 80301, USA. 


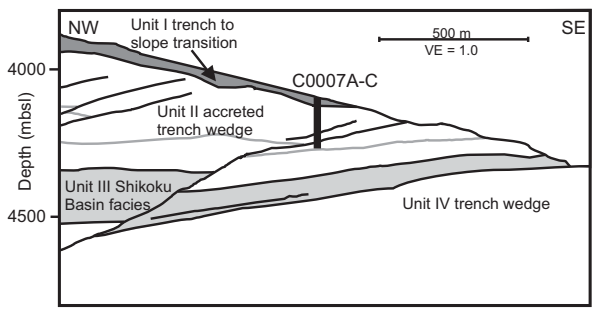

Figure 1. Simplified structural overview of frontal thrust region and Integrated Ocean Drilling Program (IODP) 316 drilling location of Hole C0007A-C (modified from Screaton et al., 2009).

with sandy turbidites, gravel, and hemipelagic mud. At least one thick $(1.7 \mathrm{~m})$ normally graded gravel sequence is present at the base of Hole $\mathrm{C} 0007 \mathrm{C}$; its grain size changes from mediumgrade gravel $(8-16 \mathrm{~mm})$ at the base to fine sand at the top. The porosity data show a strong decrease in the first $25 \mathrm{~m}$ below seafloor (mbsf; unit I), followed by a consolidation trend with depth in unit II (Kinoshita et al., 2009; Screaton et al., 2009).

\section{RESULTS}

At Hole C0007A-C, sulfate concentrations of interstitial water drop from $\sim 28 \mathrm{mM}$ at the surface to $8 \mathrm{mM}$ at $33 \mathrm{~m}$ depth (Fig. 2). Below 33 mbsf to a depth of 130 mbsf, sulfate concentrations rise slightly, followed by a sharp increase in sulfate concentration to $28 \mathrm{mM}$ at $140 \mathrm{mbsf}$. The sulfur and oxygen isotope profiles of pore-water sulfate show an inverse trend to the sulfate concentration profile. Isotope values at the top and at the base of Hole C0007A-C are similar to seawater values $\left(\delta^{34} \mathrm{~S}\right.$ $=20.5 \% o, \delta^{18} \mathrm{O}=8.7 \%$; Longinelli, 1989). The highest values were found in the zone of lowest sulfate concentration (33 mbsf): $61 \%$ o for $\delta^{34} \mathrm{~S}_{-} \mathrm{SO}_{4}$ and $28 \%$ o for $\delta^{18} \mathrm{O}-\mathrm{SO}_{4}$.

The alkalinity profile inversely mirrors the sulfate profile with a maximum concentration of $18 \mathrm{mM}$. The alkalinity increases, and when corrected for $\mathrm{Mg}$ and $\mathrm{Ca}$ loss due to carbonate precipitation, balances sulfate depletion suggesting that sulfate reduction is the major terminal electron-acceptor process for the degradation of organic carbon. Dissolved iron concentrations are generally low but show slight variations in the upper $40 \mathrm{~m}$, the maximum occurs at the transition from unit I to unit II, and a small peak is seen again at $\sim 90$ mbsf. Methane concentrations are below $60 \mu \mathrm{M}$ throughout the whole sediment column of Hole C0007A-C.

The CRS concentrations are highest in unit

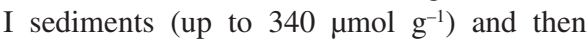
decrease and remain almost constant in the lower sediments of unit II (Fig. 2). The sulfur isotope composition of CRS is almost constant throughout the sediment column, except for a layer in unit I. The concentration of AVS is low $\left(<1 \mu \mathrm{mol} \mathrm{g}^{-1}\right)$ throughout the sediment column, with minor increases at 17 and 64 mbsf. Compared to the CRS isotope values, AVS is slightly enriched in ${ }^{34} \mathrm{~S}$. Elemental sulfur con-

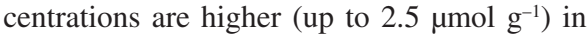
the sediments between 14 and 75 mbsf. Below and above this zone, the amount of $\mathrm{S}^{0}$ is very low (between 0.2 and $0.03 \mu \mathrm{mol} \mathrm{g}{ }^{-1}$ ). The sulfur isotope composition of $\mathrm{S}^{0}$ varies between $+12 \%$ and $-35 \%$, with high values close to the sulfur isotope composition of CRS and lowest up to $-30 \%$ offset from the sulfur isotope composition of CRS. Elevated concentrations of reactive ferric iron appear to coincide with $\mathrm{S}^{0}$ strongly depleted in ${ }^{34} \mathrm{~S}$ (except at $64 \mathrm{mbsf}$ ). The concentration of reactive iron shows values $<65 \mu \mathrm{mol} \mathrm{g}{ }^{-1}$, except for three spikes at $\sim 3,30$, and 90 mbsf, where the concentrations increase up to $170 \mu \mathrm{mol} \mathrm{g}{ }^{-1}$. The average concentration of total organic carbon is low $(<0.72$ wt $\%$ ) throughout the sediment column.

\section{DISCUSSION}

The sulfate concentration profile and isotope data of sulfate at Hole C0007A-C show two distinct sulfate reduction zones (Figs. 2 and 3). The shallow zone 1 is a typical sulfate reduction zone with downward-diffusing sulfate. Zone 3 is the deep zone where sulfate diffuses upward, indicating seawater fluid flow in the deep subsurface gravel horizon at the base of Hole C0007A-C at 160 mbsf (Expedition 316 Scientists, 2009).

The sulfur and oxygen isotope data of sulfate provide evidence that a process in addition to sulfate reduction occurs between 50 and
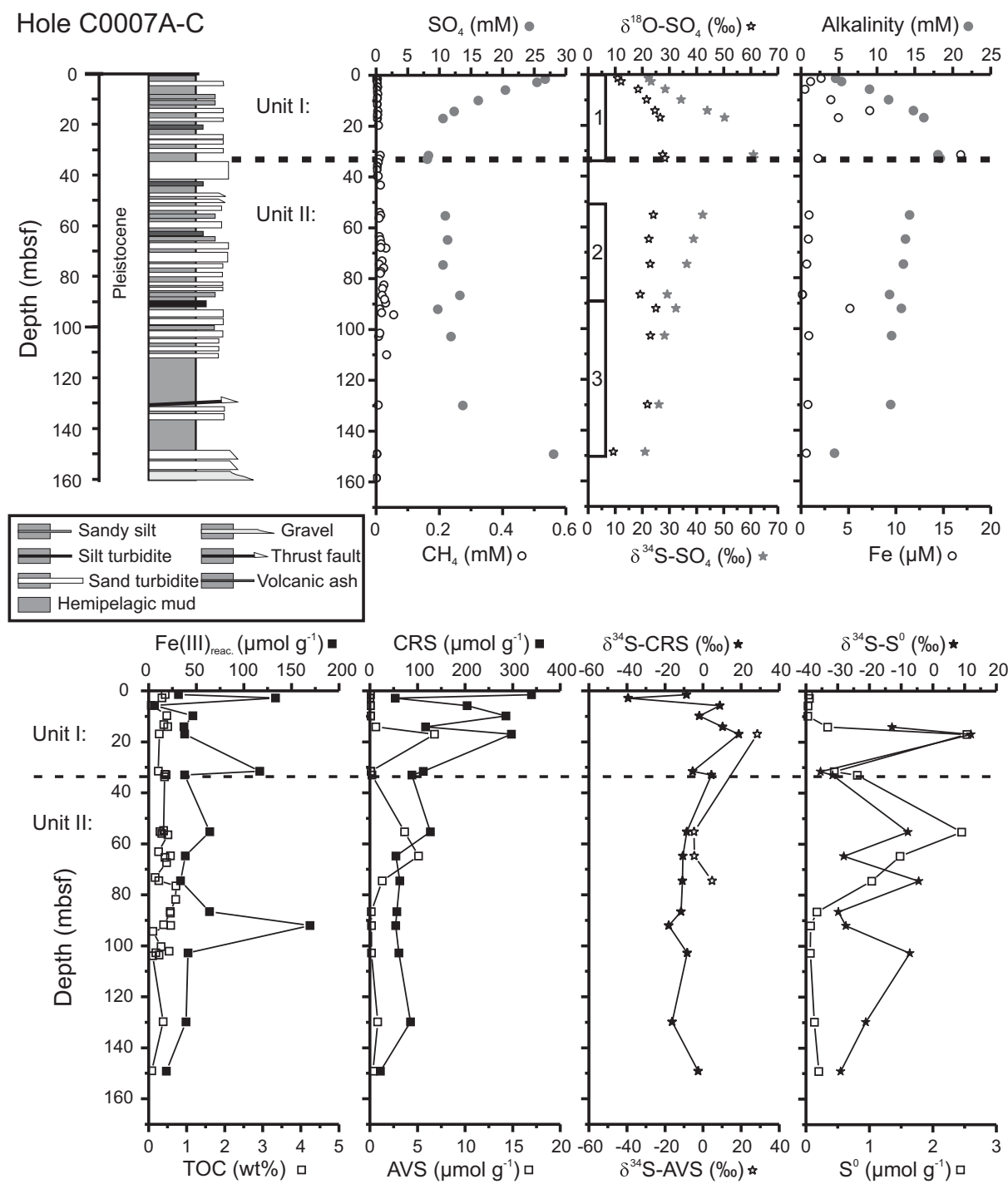

Figure 2. Pore-water and solid-phase concentration profiles of sediments from frontal thrust Hole C0007A-C. Lithostratigraphy, total organic carbon (TOC), and pore-water data are shipboard data from Integrated Ocean Drilling Program (IODP) Expedition 316 (Kinoshita et al., 2009). Zones 1-3 in sulfate isotope panel refers to depth of data plotted in Figure 3. CRSchromium reducible sulfur; AVS-acid volatile sulfur. 

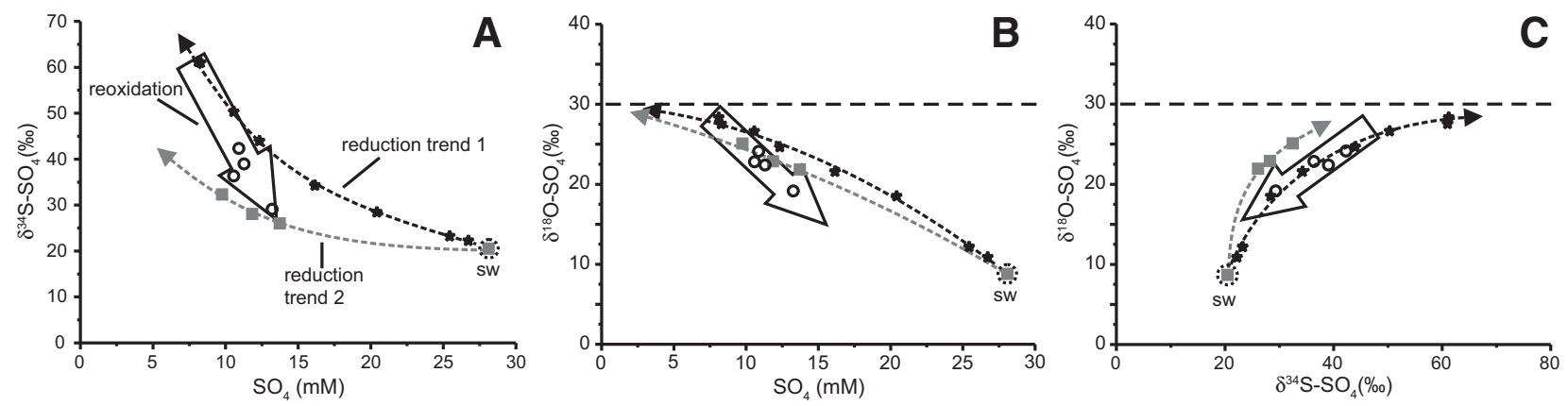

Figure 3. Sulfate concentration and isotopic composition for Hole C0007A-C. Dashed arrows show sulfate reduction trends for the sulfate profile of the upper 33 mbsf (reduction trend 1-black stars; depth interval is indicated by zone 1, Fig. 2) and for sulfate below 90 mbsf (reduction trend 2-gray squares; depth interval is indicated by zone 3, Fig. 2). Large arrow indicates reoxidation process in sulfur cycle (open circles; depth interval is indicated by zone 2 in sulfate isotope panel in Fig. 2). Dashed line plots oxygen isotope equilibrium between water and sulfate (Fritz et al., 1989), and open dotted circle shows seawater values (SW; Longinelli, 1989). A: Sulfate-sulfur isotope plot showing two different sulfate reduction trends as well as data without a reduction trend (open circles). B: Sulfate-oxygen isotope plot demonstrating that data marked with open circles cannot be explained by contamination with seawater sulfate. C: Data encased by the large arrow can be explained by mixing of sulfate affected by sulfate reduction and sulfate derived from oxidation of reduced sulfur species (e.g., sulfide).

90 mbsf (zone 2 in Fig. 2). This process (open circles, large arrow, Fig. 3) is not related to sulfate reduction occurring above or below this interval (zones 1 and 3, Fig. 2; dashed arrows, Fig. 3). Diffusive mixing of sulfate between the upper and lower sulfate reduction zones would produce a mixing line between the isotopically most enriched sulfates from the sulfate reduction trends in zone 1 and 3. Mixing of sulfate between zones 1 and 3 can be excluded as a principal cause for the observed isotope pattern because the data in zone 2 do not fall on a mixing line. Rather, there is an additional source of sulfate that is depleted in ${ }^{18} \mathrm{O}$ and ${ }^{34} \mathrm{~S}$ relative to the sulfate below and above the 50-90 mbsf zone. This depleted sulfate could either be formed in situ, supplied laterally, or be due to contamination during sampling. Cross-contamination of samples or contamination with seawater sulfate appears to be very unlikely. For instance, at least two contaminants would be necessary to produce the observed values at 86.6 mbsf $\left(\delta^{18} \mathrm{O}\right.$ of $19 \%$ and a concentration of 13.2 $\mathrm{mM}$; see Fig. 3B). Lateral advection of sulfate with a unique isotope composition could be the cause of the observed pattern, but it would not explain why such lateral advection only occurs in zone 2, whereas all zones exhibit similar fluid transport characteristics (i.e., porosity). Formation of sulfate in situ appears to be the best way to explain this observation.

Microbial disproportionation of $\mathrm{S}^{0}$ releases sulfide and sulfate into the pore water, and this process can be sustained by the reaction of sulfide oxidation with ferric iron to produce $\mathrm{S}^{0}$. The isotopic signature of the released secondary sulfate is thus dominated by bacterial disproportionation of $\mathrm{S}^{0}$, derived from sulfide depleted in ${ }^{34} \mathrm{~S}$, combined with kinetic isotope fractionation related to disproportionation reactions (Canfield et al., 1998; Cypionka et al., 1998; Böttcher et al., 2001). Thus, compared to sulfate reduction, microbial disproportionation can lead to sulfate that is depleted in ${ }^{18} \mathrm{O}$ (oxygen derived from water) and ${ }^{34} \mathrm{~S}$ (Fig. 3C). The observed shift in the oxygen and sulfur isotope composition of sulfate in the interval between 50 and 90 mbsf may therefore be derived from oxidative sulfur cycling. However, disproportionation can only occur if produced sulfide does not accumulate in the pore water (Thamdrup et al., 1993), and if $S^{0}$ is supplied via oxidation of sulfide. Even if a substantial fraction of the reactive iron pool has already been converted to pyrite (Fig. 2), it still appears that conditions for ongoing sulfide oxidation via reduction of reactive iron and scavenging of sulfide persist. Reactive iron concentrations are elevated at 90 mbsf (zone 2, Fig. 2) at sufficient levels to promote simultaneous oxidation and scavenging of sulfide.

The abundance and isotope composition of $\mathrm{S}^{0}$ provide another line of evidence for oxidative sulfur cycling. Concentration maxima within units I and II (Fig. 2) indicate that production of $\mathrm{S}^{0}$ (i.e., oxidative $\mathrm{S}$ cycling) is an ongoing process at several sediment intervals. The variable sulfur isotope composition of $\mathrm{S}^{0}$ is evidence for the absence of free sulfide in the pore water. If dissolved sulfide was continuously produced but not scavenged, then diffusive sulfide transport would occur. This would erase variations in the isotope composition of $\mathrm{S}^{0}$ at different depths because sulfide rapidly exchanges sulfur isotopes with $S^{0}$ (Fossing, 1995). As for the origin of the variable sulfur isotope composition of $\mathrm{S}^{0}$, we hypothesize that several processes variably contribute to the observed isotope signature. One process is recycling of sulfur by disproportionation, leading to sulfide strongly depleted in ${ }^{34} \mathrm{~S}$ (Canfield et al., 1998). A second process is the simultaneous sequestration of sulfide into two pools: sulfide minerals and $\mathrm{S}^{0}$ (e.g., $3 \mathrm{HS}^{-}+$ $2 \mathrm{Fe}(\mathrm{OH})_{3}+3 \mathrm{H}^{+} \leftrightarrow \mathrm{S}^{0}+2 \mathrm{FeS}+6 \mathrm{H}_{2} \mathrm{O}$; Lovley and Phillips, 1994). Corresponding increases in concentrations of AVS and $\mathrm{S}^{0}$ indicate such a coupling (Fig. 2). The partitioning of sulfide into AVS and $\mathrm{S}^{0}$ may result in considerable sulfur isotope fractionation.

\section{CONCLUSIONS}

Geochemical data from Nankai Trough Site C0007 sediments demonstrate a strong coupling between iron and sulfur cycling. The sulfur and oxygen isotopes of sulfate can be used to distinguish between different biogeochemical processes in the sediment column at Hole C0007AC. Two distinct sulfate reduction trends are observed: one for downward-diffusing sulfate and the other for upward-diffusing sulfate. These two domains appear to be separated by a zone where oxidative sulfur cycling occurs. Other sedimentary environments where sulfate is supplied from a deeper source are known, for example, from the Great Australian Bight (Feary et al., 2000) and from the central and eastern equatorial Pacific (Baker et al., 1991; Böttcher et al., 2006). In these cases, no transitional zone with oxidative sulfur cycling has been identified. Blake et al. (2006) speculated that the oxygen isotope composition of sulfate in interstitial waters from the sediments from the eastern equatorial Pacific may be affected by oxidative sulfur cycling via iron reduction. Sulfate isotope patterns from the deep subsurface Cascadian margin sediments resemble those from Nankai Trough, and Bottrell et al. (2000) attributed these patterns to deep sulfide oxidation. The identification of a sedimentary layer with oxidative sulfur cycling in the Nankai Trough is unique. Relative to the low flux of organic matter, these sediments contain large amounts of reactive iron. Under these conditions, oxidative sulfur cycling can be sustained over long time periods, and the isotope fingerprint of this process is not entirely overprinted by the isotope effects from sulfate reduction. 
Because the isotope composition of porewater sulfate is poorly preserved in the geological record, and usually only as carbonate-associated sulfate in authigenic minerals, finding evidence of oxidative sulfur cycling in the rock record is very challenging. The negative offset in the sulfur isotope composition of $\mathrm{S}^{0}$ compared to CRS offers a starting point to pin down oxidative sulfur cycling in deep biosphere environments and possibly in ancient sediments.

\section{ACKNOWLEDGMENTS}

The authors thank the captain, the crew, and the drilling crew of the Chikyu Integrated Ocean Drilling Program (IODP) 316 Expedition, as well as the technicians of Marine Works Japan. For technical assistance, we are indebted to K. Bogus, S. Ebert, K. Imhoff, S. Lilienthal, G. Klockgether, T. Max, A. Schippers, and L. Wischnewski. Our special appreciation goes to G.L. Arnold, B.K. Frieda, W.P. Gilhooly, F. Inagaki, R. Harris, and E. Screaton for helpful discussions. For constructive criticism we are grateful to T.W. Lyons and R. Raiswell. We thank S. Bottrell and an anonymous reviewer for helpful comments. This research used samples and data provided by the IODP. The research was funded by the Max Planck Society, the Helmholtz Association, and the Deutsche Forschungsgemeinschaft (DFG). Strasser was funded through DFG Research Center/Cluster of Excellence MARUM "The Ocean in the Earth System."

\section{REFERENCES CITED}

Baker, P.A., Stout, P.M., Kastner, M., and Elderfield, H., 1991, Large-scale lateral advection of seawater through oceanic crust in the central equatorial Pacific: Earth and Planetary Science Letters, v. 105 , p. 522-533, doi: 10.1016/0012-821X(91)90189-O.

Blake, R.E., Surkov, A.V., Böttcher, M.E., Ferdelman, T.G., and Jørgensen, B.B., 2006, Oxygen isotope composition of dissolved sulfate in deepsea sediments: Eastern equatorial Pacific Ocean, in Jørgensen, B.B., D’Hondt, S.L., and Miller, D.J., et al., Proceedings of the Ocean Drilling Project, Scientific results, Volume 201: Washington, D.C., U.S. Government Printing Office, doi: 10.2973/odp.proc.sr.201.116.2006.

Böttcher, M.E., Thamdrup, B., and Vennemann, T.W., 2001, Oxygen and sulfur isotope fractionation during anaerobic bacterial disproportionation of elemental sulphur: Geochimica et Cosmochimica Acta, v. 65, p. 1601-1609, doi: 10.1016/S0016-7037(00)00628-1.

Böttcher, M.E., Ferdelman, T.G., Jørgensen, B.B., Blake, R.E., Surkov, A.V., and Claypool, G.E., 2006, Sulfur isotope fractionation by the deep biosphere within sediments of the eastern equatorial Pacific and Peru margin, in Jørgensen, B.B., D’Hondt, S.L., and Miller, D.J., et al., Proceedings of the Ocean Drilling Project, Scientific results, Volume 201: Washington, D.C., U.S. Government Printing Office, doi: 10.2973/odp.proc.sr.201.109.2006

Bottrell, S.H., Parkes, R.J., Cragg, B.A., and Raiswell, R., 2000, Isotopic evidence for anoxic pyrite oxidation and stimulation of bacterial sulfate reduction in marine sediments:
Journal of the Geological Society of London, v. 157 , p. $711-714$.

Brunner, B., and Bernasconi, S.M., 2005, A revised isotope fractionation model for dissimilatory sulfate reduction in sulfate reducing bacteria: Geochimica et Cosmochimica Acta, v. 69, p. 4773-4785, doi: 10.1016/j.gca.2005.04.017.

Canfield, D.E., 1989, Reactive iron in marine sediments: Geochimica et Cosmochimica Acta, v. 53, p. 619-632, doi: 10.1016/0016-7037 (89)90005-7.

Canfield, D.E., and Thamdrup, B., 1994, The production of ${ }^{34} \mathrm{~S}$-depleted sulfide during bacterial disproportionation of elemental sulphur: Science, v. 266, p. 1973-1975, doi: 10.1126/ science. 11540246

Canfield, D.E., Thamdrup, B., and Fleischer, S., 1998, Isotope fractionation and sulfur metabolism by pure and enrichment cultures of elemental sulfur-disproportionating bacteria: Limnology and Oceanography, v. 43, p. 253-264.

Cypionka, H., Smock, A., and Böttcher, M.E., 1998, A combined pathway of sulfur compound disproportionation in Desulfovibrio desulfuricans: FEMS Microbiology Letters, v. 166, p. 181186, doi: 10.1111/j.1574-6968.1998.tb13888.x.

Expedition 316 Scientists, 2009, Expedition Site C0007, in Kinoshita, M., Tobin, H., Ashi, J., Kimura, G., Lallemant, S., Screaton, E.J., Curewitz, D., Masago, H., Moe, K.T., and the Expedition 314/315/316 Scientists, Proceedings of the Integrated Ocean Drilling Program, Volume 314/315/316: Washington, D.C., U.S. Government Printing Office, doi: 10.2204/ iodp.proc.314315316.135.2009.

Feary, D.A., Hine, A.C., Malone, M.J., et al., 2000, Proceedings of the Ocean Drilling Program, Initial reports, Leg 182: College Station, Texas, Ocean Drilling Program, CD-ROM.

Fossing, H., 1995, S-35-radiolabeling to probe biogeochemical cycling of sulphur: American Chemical Society, ACS Symposium Series, v. 612 , p. $348-364$, doi: $10.1021 /$ bk-19950612.ch019.

Fritz, P., Basharmal, G.M., Drimmie, R.J., Ibsen, J., and Qureshi, R.M., 1989, Oxygen isotope exchange between sulphate and water during bacterial reduction of sulphate: Chemical Geology, v. 79 , p. $99-105$.

Habicht, K.S., and Canfield, D.E., 2001, Isotope fractionation by sulfate-reducing natural populations and the isotopic composition of sulfide in marine sediments: Geology, v. 29, p. 555-558, doi: 10.1130/0091-7613(2001)029<0555:IFBS $\mathrm{RN}>2.0 . \mathrm{CO} ; 2$.

Jørgensen, B.B., 1982, Mineralization of organic matter in the sea bed-The role of sulphate reduction: Nature, v. 296, p. 643-645, doi: 10.1038/ 296643a0.

Jørgensen, B.B., 1990, A thiosulfate shunt in the sulfur cycle of marine sediments: Science, v. 249, p. 152-154, doi: 10.1126/science.249.4965.152.

Jørgensen, B.B., and Nelson, D.C., 2004, Sulfide oxidation in marine sediments: Geochemistry meets microbiology, in Amend, J.P., Edwards, K.J., and Lyons, T.W., eds., Sulfur Biochemistry-Past and Present: Geological Society of America Special Paper 379, p. 63-81.

Kinoshita, M., Tobin, H., Ashi, J., Kimura, G., Lallemant, S., Screaton, E.J., Curewitz, D., Masago,
H., Moe, K.T., and the Expedition 314/315/316 Scientists, 2009, NanTroSEIZE Stage 1: Investigations of seismogenesis: Nankai Trough, Japan: Proceedings of the Integrated Ocean Drilling Program, Volume 314/315/316: Washington, D.C., U.S. Government Printing Office, doi: 10.2204/iodp.proc.314315316.2009

Longinelli, A., 1989, Oxygen-18 and sulphur-34 in dissolved oceanic sulphate and phosphate, in Fritz, P., and Fontes, J.C., eds., Handbook of Environmental Isotope Geochemistry, Volume 3: Amsterdam, Elsevier, p. 219-256.

Lovley, D.R., and Phillips, E.J.P., 1994, Novel processes for anaerobic sulfate production from elemental sulfur by sulfate-reducing bacteria: Applied and Environmental Microbiology, v. 60 , p. $2394-2399$

Riedinger, N., Pfeifer, K., Kasten, S., Garming, J.F.L., Vogt, C., and Hensen, C., 2005, Diagenetic alteration of magnetic signals by anaerobic oxidation of methane related to a change in sedimentation rate: Geochimica et Cosmochimica Acta, v. 69, p. 4117-4126, doi: 10.1016/j .gca.2005.02.004.

Rudnicki, M.D., Elderfield, H., and Spiro, B., 2001, Fractionation of sulfur isotopes during bacterial sulfate reduction in deep ocean sediments at elevated temperatures: Geochimica et Cosmochimica Acta, v. 65, p. 777-789, doi: 10.1016/ S0016-7037(00)00579-2.

Screaton, E.J., Kimura, G., Curewitz, D., Moore, G., and Expeditions I.O.D.P. 314, 315, and 316 Scientific Parties, 2009, Frontal thrust activity and fluid flow at the NanTroSEIZE transect offshore the Kii Peninsula, Japan: Results of IODP Expedition 316: Geochemistry, Geophysics, Geosystems, v. 10, doi: 10.1029/2009GC002713.

Strasser, M., Moore, G.F., Kimura, G., Kitamura, Y., Kopf, A.J., Lallemant, S., Park, J.-O., Screaton, E.J., Su, X., Underwood, M.B., and Zhao, X., 2009 , Origin and evolution of a splay fault in the Nankai accretionary prism: Nature Geoscience v. 2, p. 648-652, doi: 10.1038/ngeo609.

Thamdrup, B., Finster, K., Hansen, W., and Bak, F., 1993, Bacterial disproportionation of elemental sulfur coupled to chemical reduction of iron and manganese: Applied and Environmental Microbiology, v. 59, p. 101-108.

Underwood, M.B., Moore, G.F., Taira, A., Klaus, A., Wilson, M.E.J., Fergusson, C.L., Hirano, S., Steurer, J., and the Leg 190 Shipboard Scientific Party, 2003, Sedimentary and tectonic evolution of a trench-slope basin in the Nankai subduction zone of southwest Japan: Journal of Sedimentary Research, v. 73, p. 589-602, doi 10.1306/092002730589.

Wortmann, U.G., Bernasconi, S.M., and Böttcher, M.E., 2001, Hypersulfidic deep biosphere indicates extreme sulfur isotope fractionation during single-step microbial sulfate reduction Geology, v. 29, p. 647-650, doi: 10.1130/0091 -7613(2001)029<0647:HDBIES>2.0.CO;2.

Manuscript received 1 February 2010

Revised manuscript received 26 April 2010

Manuscript accepted 3 May 2010

Printed in USA 